\title{
Diplomatic Course Bagi Siswa di SMA Diponegoro Tumpang Kabupaten Malang
}

\author{
Najamuddin Khairur Rijal ${ }^{1 *}$, Devita Prinanda ${ }^{2}$, Haryo Prasodjo ${ }^{3}$, Peggy Puspa \\ Haffsari $^{4}$ \\ 1,2,3,4 Program Studi Hubungan Internasional, Fakultas Ilmu Sosial dan Ilmu Politik \\ Universitas Muhammadiyah Malang, Jalan Raya Tlogomas No. 246 Kota Malang \\ *e-mail : najamuddin@umm.ac.id
}

Informasi Artikel

Diterima Redaksi : 26 Desember 2020

Revisi Akhir : 4 Januari 2021

Diterbitkan Online : 28 Januari 2021

Kata Kunci:

ASEAN, diplomasi, keprotokolan, PBB, sidang internasional

\begin{abstract}
Abstrak
Program pengabdian ini ditujukan untuk memberikan kursus diplomasi (diplomatic course) bagi siswa di SMA Diponegoro Tumpang, Kabupaten Malang. Hal itu didasari oleh permasalahan mitra terkait keterbatasan kapasitas dalam membekali siswa/siswi berbagai pengetahuan global, sekolah tidak memiliki kapasitas tenaga pengajar dan kapabilitas teknis operasional dalam memfasilitasi minat siswa mempelajari diplomasi dan sidang internasional serta komitmen pihak sekolah untuk mengembangkan sekolah berwawasan ASEAN dan berwawasan internasional. Untuk itu, solusi yang ditawarkan adalah pelatihan tentang diplomasi, keprotokolan, serta sidang internasional PBB dan ASEAN. Berdasarkan kegiatan yang telah dilakukan, ada beberapa temuan penting. Pertama, pelajar SMA, secara khusus SMA Diponegoro Tumpang, membutuhkan informasi dan pengetahuan mengenai wawasan internasional. Karena itu, kegiatan semacam ini menjadi penting untuk menjembatani perguruan tinggi dengan masyarakat sekolah. Kedua, pemanfaatan teknologi sebagai instrumen pembelajaran sangat diperlukan seiring dengan perkembangan teknologi informasi dan komunikasi. Karena itu, berbagai penyesuaian perlu dilakukan dalam proses pembelajaran dan diseminasi pengetahuan. Ketiga, penjelasan mengenai diplomasi, keprotokolan, serta sidang internasional dirasa tidak maksimal tanpa dilanjutkan dengan praktik atau simulasi.
\end{abstract}

target capaian dalam quality education peningkatan keterampilan yang relevan. Keterampilan yang diharapkan adalah pengembangan keterampilan tingkat tinggi kognitif dan non kognitif seperti keterampilan komunikasi, kemampuan kerja dalam tim, penyelesaian masalah dan keterampilan lainnya.[2]

Dalam kaitannya dengan itu, SMA Diponegoro Tumpang (Smadita) merupakan sekolah yang sedang mengembangkan program untuk go international. Salah satunya adalah dengan meresmikan program Smadita ASEAN School. Smadita ASEAN School sendiri merupakan visi untuk mengembangkan sekolah dan masyarakat sekolah (guru dan siswa) yang berwawasan ASEAN secara 
khusus dan berwawasan global secara umum. Hal itu merupakan respons terhadap kebutuhan lulusan yang diharapkan memiliki kemampuan bersaing dan beradaptasi dalam persaingan yang semakin kompetitif.

Sejak tahun 2017, SMA Diponegoro Tumpang menjadi mitra tim pengabdian masyarakat Program Studi Hubungan Internasional UMM. Program pengabdian yang telah dilaksanakan adalah pertama, pengembangan ASEAN We Feeling.[3] Kedua, ASEAN Class Program bagi siswa dan guru.[4] Ketiga, pendampingan pembuatan aplikasi Smadita ASEAN School (2020).

Lebih lanjut, berdasarkan diskusi tim pengabdi dengan Kepala SMA Diponegoro Tumpang Drs. Djasmani, M.Si. dan Wakil Kepala Urusan Kesiswaan Teguh Bagus Nurcahyo, S.Pd., MM diperoleh informasi bahwa pihak sekolah terus berupaya mengembangkan berbagai program yang muaranya adalah membekali siswa/siswi agar dapat memiliki pengetahuan dan keterampilan yang mampu bersaing secara nasional, regional, dan internasional.

Pihak sekolah menginginkan siswa/siswinya memiliki pengetahuan tentang isu-isu internasional sekaligus memiliki keterampilan dalam menyelesaikan masalah yang berkaitan dengan isu global. Berdasarkan pertimbangan tersebut, maka program ini diarahkan untuk melakukan kegiatan pengabdian masyarakat berupa diplomatic course. Diplomatic course sendiri merupakan kursus diplomasi singkat untuk mengasah kemampuan berpikir siswa/siswa dan membekali siswa keterampilan diplomasi tingkat dasar, khususnya dalam merespons isu-isu global kontemporer.

Namun, berdasarkan hasil diskusi tim pengabdi dengan pihak sekolah, ada beberapa hal yang menjadi permasalahan yang dihadapi oleh mitra, antara lain: Pertama, tingginya animo siswa/siswi untuk mengetahui berbagai isu internasional, namun pihak sekolah memiliki keterbatasan kapasitas dalam membekali siswa/siswi berbagai pengetahuan global. Kedua, Besarnya minat siswa/siswi untuk mengetahui dan mempraktikkan simulasi sidang internasional. Akan tetapi, pihak sekolah tidak memiliki kapasitas tenaga pengajar dan kapabilitas teknis operasional dalam memfasilitasi minat tersebut. Ketiga, Komitmen pihak sekolah untuk mengembangkan sekolah berwawasan ASEAN dan berwawasan internasional, namun belum didukung dengan kapasitas dan kapabilitas yang memadai.

Berdasarkan permasalahan di atas, maka solusi yang ditawarkan adalah perlunya pengetahuan tentang diplomasi, keprotokolan dan praktik simulasi sidang Model United Nations (MUN) dan Model ASEAN Meeting (MAM) dalam bentuk program kursus diplomasi singkat (diplomatic course). Program ini secara umum bertujuan meningkatkan pengetahuan tentang isu internasional, mengembangkan kemampuan komunikasi dan negosiasi, meningkatkan kemampuan penyelesaian konflik, mengasah kompetensi Bahasa Inggris, serta membekali keterampilan teknis sidang internasional.

\section{METODE}

Metode pelaksanaan kegiatan ini adalah pelatihan. Pelatihan dilakukan sebagai bentuk sosialisasi untuk memperkenalkan siswa/siswi tentang diplomasi, keprotokolan, dan sidang internasional PBB dan ASEAN. Sejatinya, kegiatan ini juga menggunakan metode praktik yang dilakukan melalui simulasi sidang PBB (MUN) sesuai dengan aturan dan standar prosedur pelaksanaan sidang PBB. Namun karena pandemi Covid-19, praktik/simulasi sidang internasional tidak dilaksanakan mengingat tidak adanya aktivitas pembelajaran sekolah selama pandemi sehingga direncanakan untuk dilanjutkan pada tahun berikutnya.

\section{HASIL DAN PEMBAHASAN}

Pandemi Covid-19 yang telah melanda sejak Maret 2020 mengakibatkan program pengabdian ini tidak dapat berjalan sesuai dengan perencanaan. Karena itu, tim pengabdi melakukan beberapa penyesuaian agar program tetap dapat berjalan dan tujuan yang diharapkan dapat dicapai. Penyesuaian yang dilakukan adalah pelaksanaan program yang dilaksanakan secara dalam jaringan (daring) menggunakan aplikasi Zoom. Selain itu, simulasi sidang internasional tidak dapat dilaksanakan karena harus memperhatikan 
protokol kesehatan serta pertemuan tatap muka di sekolah masih belum dilaksanakan. Namun demikian, kegiatan diplomatic course tetap dapat berjalan dengan berbagai keterbatasan yang ada. Adapun tahapan program pengabdian ini adalah sebagai berikut:

\subsection{Persiapan dan Sosialisasi}

Persiapan pelaksanaan program dilakukan melalui komunikasi dengan pihak sekolah untuk menetapkan waktu kegiatan. Komunikasi dilakukan pada 4 November 2020. Komunikasi ini menghasilkan kesepakatan waktu pelaksanaan pada Sabtu, 21 November 2020 dengan peserta dari kelas XI. Alasan siswa kelas XI yang menjadi peserta adalah karena pertimbangan relevansi dengan mata pelajaran. Keputusan itu dihasilkan oleh pihak sekolah setelah melakukan diskusi dengan dewan guru. Adapun hari Sabtu dipilih karena mempertimbangkan kesibukan belajar siswa pada hari-hari aktif, sementara Sabtu selama ini digunakan oleh sekolah untuk aktivitas ekstrakulikuler. Setelah adanya kesepakatan waktu, informasi kegiatan selanjutnya disosialisasikan oleh pihak sekolah kepada siswa kelas XI.

\subsection{Pelaksanaan}

Pelaksanaan kegiatan dilakukan secara daring menggunakan aplikasi Zoom. Kegiatan ini awalnya diikuti peserta sebanyak 86 orang, namun peserta yang mengikuti hingga akhir sebanyak 67 siswa. Peserta lainnya tidak dapat mengikuti hingga akhir karena berbagai alasan teknis, seperti kendala jaringan dan perangkat.

Kegiatan diplomatic course diawali oleh sambutan dari Wakil Kepala Urusan Kesiswaan SMA Diponegoro Tumpang Teguh Bagus Nurcahyo, S.Pd., MM serta pengantar diplomatic course bagi siswa SMA Diponegoro Tumpang oleh Najamuddin Khairur Rijal, M.Hub.Int. Dalam sambutannya, pihak sekolah menyambut baik dan memandang penting kegiatan ini sebagai bagian dari upaya mewujudkan visi sekolah. Bahkan, pihak sekolah berharap bahwa kegiatan semacam ini perlu dilanjutkan dan terus dikembangkan guna menambah wawasan internasional serta meningkatkan kompetensi para siswa.

Setelah pembukaan, kemudian dilanjutkan dengan materi. Ada empat materi yang juga disampaikan oleh empat pemateri, sebagai berikut: (1) Pengantar Diplomasi dan Praktiknya di ASEAN oleh Devita Prinanda, M.Hub.Int.; Keprotokolan Internasional dan Praktiknya di ASEAN oleh Peggy Puspa Haffsari, M.Sc., M.Si.; (3) Pengantar Sidang Internasional: Model United Nations (MUN) oleh Syelda Titania Sukarno Putri (UMM MUN Club); (4) Pengantar Sidang Internasional: Model ASEAN Meeting (MAM) oleh Shinta Liana Melati (UMM MUN Club).

Materi I memberikan pengantar dan pengetahuan dasar tentang diplomasi serta gambaran tentang praktik diplomasi di ASEAN. Pemateri memaparkan mengenai apa itu diplomasi dan mengapa diplomasi itu penting. Kemudian peserta diajak untuk membedakan antara diplomasi, diplomat, dan diplomatik. Selanjutnya, dipaparkan mengenai praktik diplomasi dari masa ke masa, sejak zaman kuno hingga era kontemporer dan bagaimana perjalanan historis diplomasi di era modern. Selanjutnya pemaparan tentang negosiasi sebagai unsur penting dalam diplomasi serta gambaran mengenai praktik diplomasi di ASEAN.

Materi II membahas mengenai keprotokolan dan bagaimana praktik keprotokolan di ASEAN. Pemateri mengawali materi dengan menjelaskan tentang definisi protokol dan keprotokolan. Kemudian menjelaskan mengenai dasar hukum keprotokolan di Indonesia yang diatur dalam Undang-Undang Nomor 9 Tahun 2010. Dalam UU tersebut diatur bahwa keprotokoleran berkaitan dengan serangkaian kegiatan yang berkaitan dengan aturan dalam acara kenegaraan atau acara resmi yang meliputi aturan mengenai tata tempat, tata upacara, dan tata penghormatan sebagai bentuk penghormatan kepada seseorang sesuai dengan jabatan dan atau kedudukan dalam negara, pemerintah atau masyarakat.

Dalam konteks ASEAN, ASEAN memiliki buku panduan praktik dan protokol di ASEAN yang dimaksudkan sebagai referensi ke negara-negara anggota 
ASEAN serta pihak-pihak seperti mitra dialog dan pihak eksternal. Dijelaskan pula mengenai susunan acara dalam pertemuan ASEAN, tata urutan bendera negara-negara anggota ASEAN, hingga pengaturan tempat duduk dalam berbagai forum ASEAN.

Materi III memberikan gambaran mengenai praktik sidang MUN. Pemateri memberikan penjelasan tentang apa dan bagaimana MUN serta bagaimana teknis dan pelaksanaan MUN. Pemateri juga memberikan gambaran mengenai position paper, working paper, dan draft resolution sebagai tiga dokumen penting yang perlu dipersiapkan oleh setiap delegasi dalam MUN. Kemudian bagaimana teknik negosiasi dan mekanisme lobi untuk mencapai kesepakatan terkait motion dan perdebatan selama sidang. Pada bagian akhir, pemateri memberikan penjelasan mengenai berbagai manfaat dari MUN seperti belajar bernegosiasi, melatih keterampilan analitis, menulis, dan berpikir kritis, serta belajar upaya penyelesaian masalah.

Materi IV membahas mengenai gambaran praktik sidang di ASEAN atau MAM. Dijelaskan bahwa MAM berbeda dengan MUN baik secara teknis maupun secara prosedur pelaksanaan. Perbedaan penting adalah pada mekanisme pengambilan keputusan. Pada MUN, pengambilan keputusan melalui voting, namun pada MAM pengambilan keputusan dilakukan secara konsensus dan konsultasi. Kemudian, luaran dalam MUN adalah working paper serta draft resolusi yang akan disetujui oleh semua delegasi. Sementara dalam MAM, luarannya adalah chairman statement atau pernyataan dari Keketuaan ASEAN mengenai keputusan yang dihasilkan.

Di akhir materi, dibuka sesi tanya jawab yang diikuti secara antusias oleh peserta. Beberapa pertanyaan yang diajukan misalnya terkait isu-isu keamanan di ASEAN hingga mengenai keikutsertaan dalam MUN. Beberapa siswa mengaku tertarik untuk mengikuti MUN. Hal ini direspons oleh pemateri bahwa MUN dapat diikuti oleh pelajar SMA dan berbagai kegiatan MUN baik secara nasional maupun internasional membuka kesempatan bagi keikutsertaan delegasi dari pelajar SMA.
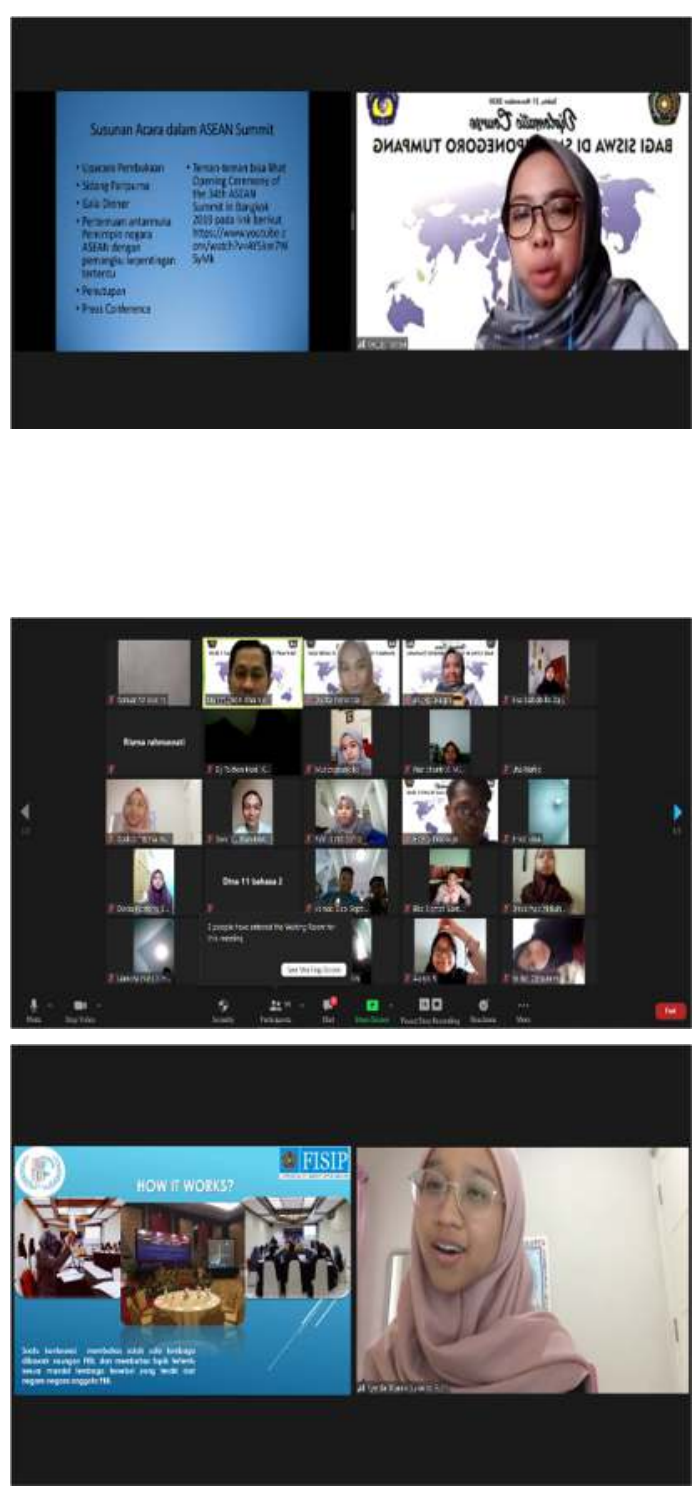

Gambar 1. Screenshoot Kegiatan Diplomatic Course

\subsection{Evaluasi}

Berdasarkan kegiatan yang telah dilaksanakan ada beberapa hal yang menjadi catatan penting, yaitu terkait waktu pelaksanaan dan kendala teknis. Namun demikian, berdasarkan survei kepada para peserta, kegiatan ini secara umum dinilai penting dan bermanfaat untuk memberikan pengetahuan baru dan wawasan internasional.

Namun demikian, berdasarkan survei kepada para peserta, kegiatan ini secara umum dinilai penting dan bermanfaat untuk memberikan pengetahuan baru dan wawasan internasional. Misalnya pengakuan dari Yanuar Wibisono bahwa, "Setelah mengikuti acara diplomatic course saya menjadi lebih tahu dan mengerti 
bagaimana acara acara diplomatik

kenegaraan diselenggarakan." Lorentza Dinar Alfatia mengatakan bahwa, "Pembelajarannya jelas dan menyenangkan saya jadi tahu banyak informasi baru terutama tentang MUN. Informasi ini pasti sangat bermanfaat buat saya kelak." Adapun Dhea Puja Fariska berpendapat bahwa, "Saya menjadi lebih paham mengenai hubungan internasional, tentang diplomat diplomasi dan diplomatik." Demikian pula semua peserta memberikan apresiasi positif terhadap kegiatan dan materi yang telah disampaikan.

Selanjutnya, ada beberapa masukan tindak lanjut untuk kegiatan selanjutnya dari peserta. Seperti masukan dari Muhammad Fikri Nasrulloh yang meminta kegiatan semacam ini dapat dilanjutkan secara langsung (tatap muka) karena informasinya penting dan dibutuhkan. Atau Firdays Royhillatul Hamzah yang meminta kegiatan dilanjutkan, "Semoga kegiatan ini tahun depan masih lanjut karena dengan kegiatan ini kami bisa mengasah sekaligus belajar untuk persiapan ujian yang akan datang." Demikian pula Rizky Martha Cahya Puspita yang mengharapkan adanya kegiatan lain yang fokus pada diplomasi.

Adapun rencana tidak lanjut dari pihak sekolah yang disampaikan oleh Wakil Kepala Urusan Kesiswaan Teguh Bagus Nurcahyo adalah perlunya seminar atau workshop tentang Kualifikasi Kompetensi Nasional Indonesia (KKNI) di tingkat ASEAN dalam hubungannya dengan uji kompetensi dari Badan Nasional Sertifikasi Profesi (BNSP). Mengingat, sertifikat kompetensi saat ini menjadi kebutuhan penting terutama untuk menghadapi liberalisasi tenaga kerja dalam kerangka Masyarakat Ekonomi ASEAN.

Berdasarkan kegiatan diplomatic course yang telah dilakukan, ada beberapa temuan penting yang perlu dibahas. Pertama, pelajar SMA, secara khusus SMA Diponegoro Tumpang, membutuhkan informasi dan pengetahuan mengenai wawasan internasional, termasuk di dalamnya terkait diplomasi, keprotokolan, dan sidang internasional. Karena itu, kegiatan semacam ini menjadi penting untuk menjembatani antara fungsi perguruan tinggi sebagai produsen pengetahuan dengan sekolah. Apalagi selama ini, perguruan tinggi seolah berjarak dengan masyarakat dan pengetahuan yang diproduksi tidak membumi serta cenderung belum memberikan kontribusi nyata bagi masyarakat, termasuk masyarakat sekolah.[5]

Berkaitan dengan itu pula, kemitraan dan kolaborasi antara perguruan tinggi dengan sekolah perlu terus ditingkatkan melalui berbagai aktivitas, baik untuk pengembangan siswa maupun guru. Sebab, kolaborasi perguruan tinggi dan sekolah berpotensi besar untuk meningkatkan kualitas hasil belajar.[6] Hal ini juga penting untuk membangun persepsi positif siswa terhadap pendidikan tinggi yang selanjutnya berpengaruh terhadap arah pendidikan merek di masa mendatang.[7]

Kedua, pemanfaatan teknologi sebagai instrumen pembelajaran sangat diperlukan.[8], [9] Hal ini seiring juga dengan tuntutan perkembangan teknologi informasi dan komunikasi di era Revolusi Industri 4.0.[10] Karena itu, berbagai penyesuaian perlu dilakukan dalam proses pembelajaran dan diseminasi pengetahuan. Penyesuaian itu juga tidak terlepas dengan pandemi Covid-19 yang menjadi tantangan tersendiri bagi dunia pendidikan.[11]

Penyesuaian itu salah satunya melalui program pengabdian masyarakat ini yang dilakukan dengan memanfaatkan instrumen perkembangan teknologi, seperti Zoom. Namun demikian, di sisi lain, pemanfaatan teknologi juga memiliki tantangan tersendiri karena tidak adanya interaksi personal secara langsung dan tatap muka. Karena itu, diperlukan desain pembelajaran dan diseminasi pengetahuan berbasis teknologi yang mampu meningkatkan interaksi dan komunikasi personal antar semua pihak yang terlibat.

Ketiga, penjelasan mengenai diplomasi, keprotokolan, serta sidang internasional dirasa tidak maksimal tanpa dilanjutkan dengan praktik atau simulasi. Sebab, keterampilan diplomasi dan negosiasi serta keterampilan sidang internasional, baik MUN dan MAM hanya bisa diasah dan digali melalui praktik langsung. Artinya, penjelasan tekstual saja belum cukup sehingga perlu partisipasi melalui praktik. Karena itu, dalam program pengabdian masyarakat menjadi penting adanya 
pelatihan dan pendampingan melalui praktik/simulasi langsung.

Mengingat pula, bahwa pembelajaran berbasis praktik merupakan salah metode efektif dalam proses pendidikan dan pengajaran.[12] Hal itu juga tidak terlepas dari manfaat praktik/simulasi sidang internasional yang dapat melatih soft-skills, seperti bekerja dalam tim, kemampuan memecahkan masalah, keterampilan berbicara, mengasah kemampuan berbahasa Inggris, berpikir dan menulis kritis, serta kemampuan negosiasi.[13] Kesemuanya itu dapat diasah melalui praktik langsung.

\section{KESIMPULAN}

Program pengabdian masyarakat ini menjadi solusi bagi SMA Diponegoro Tumpang dalam usaha memberikan wawasan internasional kepada siswa dalam rangka mewujudkan visi Smadita ASEAN School. Program ini dinilai penting bagi pihak sekolah karena memberikan pengetahuan tentang diplomasi, keprotokolan internasional, serta sidang internasional yang tidak diperoleh dalam pembelajaran di kelas. Meskipun dilaksanakan secara daring, kegiatan ini dapat diikuti dengan baik oleh peserta dan para peserta menunjukkan antusiasme yang tinggi selama kegiatan. Program ini sekaligus menjembatani kontribusi perguruan tinggi bagi diseminasi informasi dan pengetahuan kepada masyarakat luas.

\section{SARAN}

Program ini perlu ditindaklanjuti untuk pendalaman pengetahuan diplomasi, keprotokolan dan sidang internasional melalui kegiatan simulasi sidang PBB dan ASEAN. Simulasi sidang dinilai penting dan perlu dilakukan karena pengetahuan tentang hal tersebut bersifat teknis dan praktis sehingga tidak cukup hanya dijelaskan tanpa dipraktikkan secara langsung.

\section{UCAPAN TERIMA KASIH}

Ucapan terima kasih kepada Fakultas Ilmu Sosial dan Ilmu Politik serta Direktorat Penelitian dan Pengabdian kepada Masyarakat Universitas Muhammadiyah Malang yang telah mendanai program pengabdian masyarakat ini melalui skim Block Grant Tahun 2020.

\section{REFERENSI}

[1] SDGs, "Apa Itu SDGs. Retrieved from Sustainable Development Goals:,"

www.sdg2030indonesia.org, 2017. [Online]. Available: https://www.sdg2030indonesia.org/p age/8-apa-itu. [Accessed: 23-Apr2020].

[2] Global Campaign for Education, "SDG4's 10 targets," www.campaignforeducation.org,

2018. [Online]. Available: https://www.campaignforeducation. org/en/who-we-are/the-

international-education-framework2/the-sustainable-development-goal$4 / \operatorname{sdg} 4 \mathrm{~s}-10$ targets/?gclid=Cj0KCQiAyp7yBRC wARIsABfQsnT0mDW_DUcxVCc BrxUkgIk0JKo3KeiT1wTN1c9Mu AIp710qbpwA6z4aAi9VEALw_wc B. [Accessed: 23-Apr-2020].

[3] N. K. Rijal, D. E. Kurniawati, and D. F. Suhermanto, "Pengembangan ASEAN We Feeling di SMA Diponegoro Tumpang Kabupaten Malang," J. Balireso, vol. 3, no. 2, pp. 151-165, 2018.

[4] N. K. Rijal, H. Prasodjo, and R. A. T. Cahyani, "Asean Class Program Bagi Guru di SMA Diponegoro Tumpang, Kabupaten Malang, Jawa Timur," J-ABDIPAMAS (Jurnal Pengabdi. Kpd. Masyarakat), vol. 4, no. 1, pp. 135-141, 2020.

[5] A. Nuryatno, "Kritik Budaya Akademik di Pendidikan Tinggi," $J$. Soc. Media, vol. 1, no. 1, pp. 35-42, 2017.

[6] Z. Zulfiani, Y. Herlanti, and A. Sofyan, "Kajian Penerapan Pendampingan Penelitian Tindakan Kelas Kolaboratif antara Perguruan Tinggi dan Sekolah," J. Cakrawala Pendidik., vol. 15, no. 2, pp. 273283, 2016.

[7] Triyono and R. Dwi Febriani, "Persepsi Peserta Didik Sekolah 
Menengah Atas Terhadap

Pendidikan Lanjutan," J. Pendidik. dan Pembelajaran, vol. 3, no. 1, pp. 70-77, 2018.

[8] S. Adam and M. T. Syastra, "Pemanfaatan Media Pembelajaran Berbasis Teknologi Informasi Bagi Siswa Kelas X SMA Ananda Batam," CBIS J., vol. 3, no. 2, pp. 78-90, 2015.

[9] Kusmayadi, "Peningkatan Kemampuan dalam Menggunakan Teknologi Informasi dan Komunikasi sebagai Media Pembelajaran yang Efektif Bagi Guru MIS Nahdlatul Umah Kalirahayu dan MIS Miftahul Ulum Kalirahayu Losari Cirebon," Syntax Lit. J. Ilm. Indones., vol. 2, no. 5, pp. 85-102, 2017.

[10] D. Karnengi and Iswahyudi, "Tantangan Pembelajaran Berbasis Teknologi Informasi Era Revolusi Industri 4.0 di SMA Negeri 5 Prabumulih," Pros. Semin. Nas. Pendidik. Progr. Pascasarj. Univ. PGRI Palembang, vol. 1, no. 1, pp. 138-147, 2019.

[11] U. H. Salsabila, L. I. Sari, K. H. Lathif, A. P. Lestari, and A. Ayuning, "Peran Teknologi dalam Pembelajaran di Masa Pandemi Covid-19," Al-Mutharahah J. Penelit. dan Kaji. Sos. Keagamaan, vol. 17, no. 2, pp. 188-198, 2020.

[12] L. Kurniawati, R. O. Akbar, and M. Ali Misri, "Pengaruh Penerapan Metode Pembelajaran Praktikum Terhadap Keterampilan Berpikir Kritis Matematika Siswa Kelas VIII SMP N 3 Sumber Kabupaten Cirebon," EduMa Math. Educ. Learn. Teach., vol. 4, no. 2, pp. $62-$ 74, 2015.

[13] B. T. Azkiya, "Model United Nations dan Manfaat yang Didapat Kalau Ikut Program Ini," Sindonews.com, 2020. [Online]. Available:

https://gensindo.sindonews.com/rea d/78578/700/model-united-nationsdan-manfaat-yang-didapat-kalauikut-program-ini1592888780? showpage $=$ all. 